\title{
Studi Mengenai Hubungan antara Kelecakan dengan Faktor Air-Semen dan Kadar Air dalam Campuran Beton Cara SNI pada Kondisi Agregat Kering Udara
}

\author{
DIKA DWI ASTANTO, PRIYANTO SAELAN \\ Jurusan Teknik Sipil, Institut Teknologi Nasional, Bandung \\ Email: astantodika@gmail.com
}

\begin{abstract}
ABSTRAK
Kelecakan campuran beton dapat didefinisikan sebagai tingkat kemudahan campuran beton untuk diaduk, diangkut, dituang, dan dipadatkan. Sifat kemudahan campuran beton untuk dikerjakan dipengaruhi oleh beberapa faktor, yaitu jumlah air, faktor air-semen yang digunakan, jumlah agregat dalam campuran beton, dan ukuran butiran agregat serta gradasinya. Hubungan antara kelecakan dengan faktor air-semen, dan jumlah agregat yang digunakan tidak diperlihatkan dengan jelas pada perancangan campuran beton cara SNI. Oleh karena itu perlu dilakukan penelitian dengan mengacu kepada cara SNI dengan menggunakan agregat kering udara berukuran $10 \mathrm{~mm}, 20 \mathrm{~mm}$, dan $40 \mathrm{~mm}$ serta faktor air-semen sebesar 0,40;0,45;0,50;0,55; dan 0,60 dengan rentang nilai slump 30-60 mm, dan 60-180 mm. Hasil penelitian menunjukkan bahwa kelecakan tidak dipengaruhi oleh faktor air-semen tetapi hanya dipengaruhi oleh jumlah air dan ukuran butiran agregat.
\end{abstract}

Kata kunci: kelecakan, faktor air-semen, jumlah air

\begin{abstract}
Concrete workability can be defined as the level of easiness of concrete mix to be mixed, transported, casted, and compacted. Workability is influenced by several factors, such as amount of water, water-cement ratio, aggregate amount in concrete mix, and the size and gradation of aggregate. The relation between concrete workability, water-cement ratio, and the amount of aggregate used is not clearly shown in SNI method. This research was carried out to prove whether or not workability is not influenced by water-cement ratio in SNI method. Experiments was carried out using air dry aggregates $10 \mathrm{~mm}, 20 \mathrm{~mm}$, and $40 \mathrm{~mm}$ size, watercement ratio used are $0.40 ; 0.45 ; 0.50 ; 0.55 ;$ and 0.60 . Workability was designed in 30-60 mm and 60-180 mm slump. The results showed that workability in SNI method is not influenced by water-cement ratio but only influenced by the amount of water and maximum size of coarse aggregate.
\end{abstract}

Keywords: workability, water-cement ratio, amount of water 


\section{PENDAHULUAN}

Kelecakan berkaitan dengan tingkat kemudahan campuran beton untuk diaduk, diangkut, dituang dan dipadatkan. Sifat kemudahan dikerjakan pada campuran beton dipengaruhi oleh beberapa faktor, yaitu jumlah air, faktor air-semen yang digunakan, jumlah agregat dalam campuran beton, dan ukuran butiran agregat serta gradasinya. Fenomena hubungan antara kelecakan dengan faktor air-semen, dan jumlah agregat yang digunakan tidak diperlihatkan dengan jelas pada perancangan campuran beton cara SNI. Perancangan campuran beton cara SNI hanya memperlihatkan hubungan antara kelecakan dengan ukuran maksimum agregat serta jumlah air yang digunakan. Faktor air-semen digunakan untuk mencapai kuat tekan yang direncanakan serta untuk menentukan persentase pasir dalam agregat gabungan untuk slump campuran beton yang diinginkan. Mengingat kelecakan campuran beton ditentukan oleh banyak faktor-faktor seperti yang telah diuraikan, maka sebaiknya dalam cara perancangan campuran beton, faktor-faktor yang menentukan tersebut turut diperhitungkan untuk mendapatkan jumlah air yang dibutuhkan. Mengingat kondisi umum agregat yang berada di lapangan adalah kondisi kering udara maka jumlah air yang diperlukan sebaiknya didasarkan pada kondisi ini.

\section{TINJAUAN PUSTAKA}

\subsection{Faktor-Faktor Yang Mempengaruhi Kelecakan Campuran Beton Segar}

Kelecakan merupakan tingkat kemudahan campuran beton untuk diaduk, diangkut, dituang, dan dipadatkan. Kelecakan campuran beton segar dipengaruhi oleh beberapa faktor yaitu:

1. Jumlah Air

Semakin besar jumlah air yang digunakan, maka campuran beton segar menjadi encer dan mudah untuk dikerjakan. Namun, besarnya jumlah air yang digunakan pada campuran beton segar akan menurunkan kekuatan beton.

2. Faktor Air-Semen

Faktor air-semen yang besar menandakan jumlah air yang digunakan lebih besar dari jumlah semen. Semakin besar faktor air-semen yang digunakan, maka campuran beton akan semakin mudah untuk dikerjakan jika kadar semennya tetap. Namun faktor air-semen yang besar dapat menurunkan kekuatan beton. Menurut Mulyono, T. (2003), pada umumnya nilai faktor air-semen minimum yang digunakan sekitar 0,4 dan maksimum sekitar 0,65. Pengaruh faktor air-semen terhadap kelecakan campuran beton dapat dilihat berdasarkan penelitian Dreux Gorisse pada Gambar 1. Jika ukuran butiran agregat maksimum yang digunakan lebih besar atau lebih kecil dari $20 \mathrm{~mm}$, maka jumlah air $(w)$ harus dikoreksi dengan faktor koreksi menggunakan Tabel 1.

Tabel 1. Koreksi Kadar Air

\begin{tabular}{lccccccc}
\hline Ukuran Maksimum Agregat [mm] & 5 & 8 & 12,5 & 20 & 31,5 & 50 & 80 \\
\hline Koreksi Jumlah Air [\%] & 15 & 9 & 4 & 0 & -4 & -8 & -12 \\
\hline
\end{tabular}

\section{Ukuran Butiran Agregat}

Menurut Arjanggi, S. D. (2012), semakin besar ukuran agregat yang digunakan pada campuran beton, maka semakin sedikit jumlah air yang dibutuhkan. Jika semakin kecil ukuran agregat, maka jumlah air yang dibutuhkan semakin besar dikarenakan luas permukaan butiran agregat yang harus dibasahi semakin banyak. 
Studi Mengenai Hubungan antara Kelecakan dengan Faktor Air-Semen dan Kadar Air dalam Campuran Beton Cara SNI pada Kondisi Agregat Kering Udara

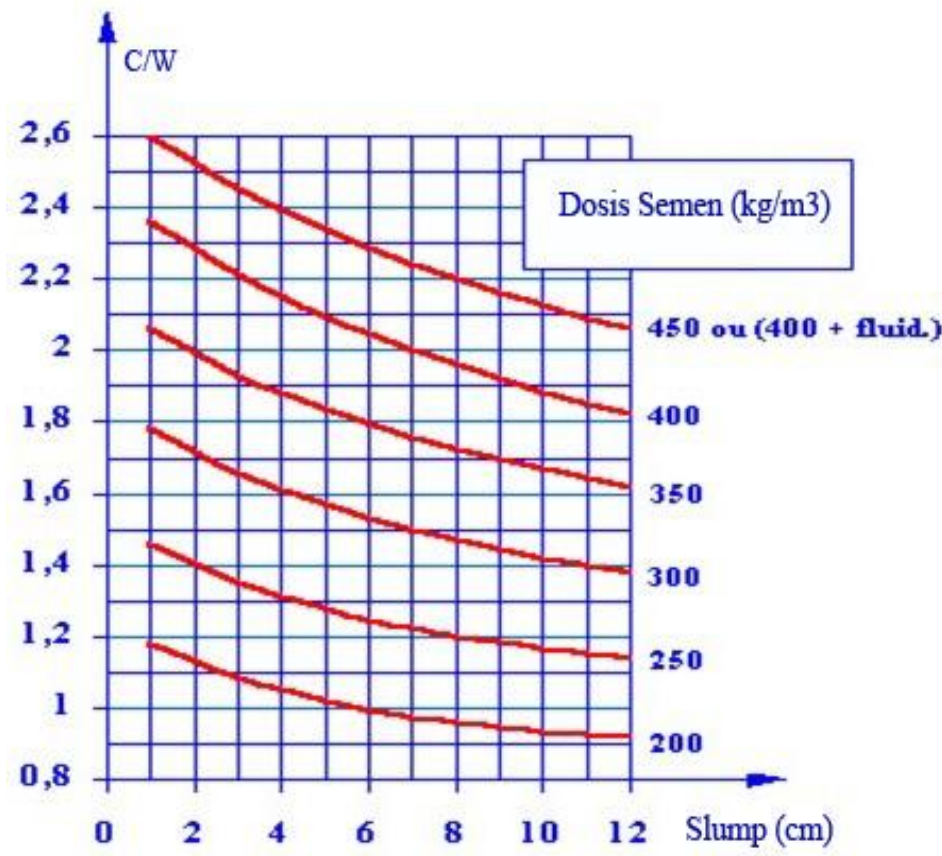

Gambar 1. Hubungan $c / w$ dengan nilai slump dan dosis semen kondisi kering udara (Sumber: Dreux 1979 dalam Azka, A., 2016)

\subsection{Kajian Mengenai Kelecakan Campuran Beton Segar Pada Perancangan Campuran Beton Cara SNI}

Kelecakan campuran beton segar pada perancangan campuran beton cara SNI didasarkan pada penentuan perkiraan kadar air bebas yang dibutuhkan, seperti pada Tabel 2.

Tabel 2. Perkiraan Kadar Air Bebas $\left[\mathrm{kg} / \mathrm{m}^{3}\right]$ yang Dibutuhkan untuk Beberapa Tingkat Kemudahan Pengerjaan Adukan Beton

\begin{tabular}{clcccc}
\hline $\begin{array}{c}\text { Ukuran Besar Butir } \\
\text { Agregat Maksimum } \\
{[\mathbf{m m}]}\end{array}$ & \multicolumn{1}{c}{ Jenis Agregat } & \multicolumn{4}{c}{ Slump [mm] } \\
\cline { 3 - 6 } & & $\mathbf{0 - 1 0}$ & $\mathbf{1 0 - 3 0}$ & $\mathbf{3 0 - 6 0}$ & $\mathbf{6 0 - 1 8 0}$ \\
\hline \multirow{2}{*}{10} & Batu tak dipecahkan & 150 & 180 & 205 & 225 \\
& Batu pecah & 180 & 205 & 230 & 250 \\
\hline \multirow{2}{*}{20} & Batu tak dipecahkan & 135 & 160 & 180 & 195 \\
& Batu pecah & 170 & 190 & 210 & 225 \\
\hline \multirow{2}{*}{40} & Batu tak dipecahkan & 115 & 140 & 160 & 175 \\
& Batu pecah & 155 & 175 & 190 & 205 \\
\hline
\end{tabular}

(Sumber: SNI 03-2834-2000)

Berdasarkan Tabel 2 dapat diketahui bahwa kelecakan campuran beton segar cara SNI tidak dipengaruhi oleh faktor air-semen. Hal ini berarti bahwa untuk suatu ukuran maksimum butiran agregat, berapapun nilai faktor air-semen, jumlah air yang dibutuhkan untuk mencapai suatu tingkat kelecakan atau suatu nilai s/ump, akan sama. Konsep kelecakan yang diberikan pada Tabel 2 berbeda dengan konsep kelecakan yang diberikan pada Gambar 1 dimana faktor air-semen sangat menentukan nilai s/ump. Jika konsep kelecakan cara SNI dikajibanding menggunakan konsep kelecakan cara Dreux Gorrise maka hasilnya tertera pada Tabel 3, Tabel 4, dan Tabel 5. 
Tabel 3. Kebutuhan Air $\left[\mathrm{kg} / \mathrm{m}^{3}\right]$ dalam Campuran Beton untuk Ukuran Maksimum Agregat Kasar 10 mm

\begin{tabular}{ccccc}
\hline \multirow{w}{*}{$\boldsymbol{c} \boldsymbol{c}$} & \multicolumn{2}{c}{ Slump 30-60 $\mathbf{~ m m}$} & \multicolumn{2}{c}{ Slump 60-180 $\mathbf{~ m m ~}$} \\
\cline { 2 - 5 } & $\begin{array}{c}\text { SNI } \\
\text { (kondisi SSD) }\end{array}$ & $\begin{array}{c}\text { Dreux } \\
\text { (kondisi kering udara) }\end{array}$ & $\begin{array}{c}\text { SNI } \\
\text { (kondisi SSD) }\end{array}$ & $\begin{array}{c}\text { Dreux } \\
\text { (kondisi kering udara) }\end{array}$ \\
\hline 0,40 & 213,33 & 222,36 & 233,33 & 244,16 \\
\hline 0,45 & 213,33 & 223,18 & 233,33 & 245,25 \\
\hline 0,50 & 213,33 & 220,73 & 233,33 & 239,8 \\
\hline 0,55 & 213,33 & 221,82 & 233,33 & 245,80 \\
\hline 0,60 & 213,33 & 219,09 & 233,33 & 241,98 \\
\hline
\end{tabular}

Tabel 4. Kebutuhan Air $\left[\mathrm{kg} / \mathrm{m}^{3}\right]$ dalam Campuran Beton untuk Ukuran Maksimum Agregat Kasar 20 mm

\begin{tabular}{ccccc}
\hline \multirow{w}{*}{$\boldsymbol{c} \boldsymbol{c}$} & \multicolumn{2}{c}{ Slump 30-60 $\mathbf{~ m m}$} & \multicolumn{2}{c}{ Slump 60-180 $\mathbf{~ m m ~}$} \\
\cline { 2 - 5 } & $\begin{array}{c}\text { SNI } \\
\text { (kondisi SSD) }\end{array}$ & $\begin{array}{c}\text { Dreux } \\
\text { (kondisi kering udara) }\end{array}$ & $\begin{array}{c}\text { SNI } \\
\text { (kondisi SSD) }\end{array}$ & $\begin{array}{c}\text { Dreux } \\
\text { (kondisi kering udara) }\end{array}$ \\
\hline 0,40 & 190 & 204 & 205 & 224 \\
\hline 0,45 & 190 & 204,75 & 205 & 225 \\
\hline 0,50 & 190 & 202,5 & 205 & 220 \\
\hline 0,55 & 190 & 203,5 & 205 & 225,5 \\
\hline 0,60 & 190 & 201 & 205 & 222 \\
\hline
\end{tabular}

Tabel 5. Kebutuhan Air $\left[\mathrm{kg} / \mathrm{m}^{3}\right]$ dalam Campuran Beton untuk Ukuran Maksimum Agregat Kasar 40 mm

\begin{tabular}{ccccc}
\hline \multirow{w}{*}{$\boldsymbol{c} \boldsymbol{c}$} & \multicolumn{2}{c}{ Slump 30-60 $\mathbf{~ m m}$} & \multicolumn{2}{c}{ Slump 60-180 mm } \\
\cline { 2 - 5 } & $\begin{array}{c}\text { SNI } \\
\text { (kondisi SSD) }\end{array}$ & $\begin{array}{c}\text { Dreux } \\
\text { (kondisi kering udara) }\end{array}$ & $\begin{array}{c}\text { SNI } \\
\text { (kondisi SSD) }\end{array}$ & $\begin{array}{c}\text { Dreux } \\
\text { (kondisi kering udara) }\end{array}$ \\
\hline 0,40 & 170 & 187,68 & 185 & 206,08 \\
\hline 0,45 & 170 & 188,37 & 185 & 207 \\
\hline 0,50 & 170 & 186,3 & 185 & 202,4 \\
\hline 0,55 & 170 & 187,22 & 185 & 207,46 \\
\hline 0,60 & 170 & 184,92 & 185 & 204,24 \\
\hline
\end{tabular}

Jika kadar air pada kondisi kering udara digunakan kadar air rata-rata maka dapat diajukan pendekatan kebutuhan air dalam campuran beton pada kondisi kering udara untuk s/ump $30 \mathrm{~mm}-60 \mathrm{~mm}$, dan slump $60 \mathrm{~mm}-180 \mathrm{~mm}$ seperti pada Tabel 6, Tabel 7, dan Tabel 8.

Tabel 6. Pendekatan Kebutuhan Air [ $\mathrm{kg} / \mathrm{m}^{3}$ ] Cara SNI dalam Campuran Beton untuk Ukuran Maksimum Agregat Kasar 10 mm Kering Udara

\begin{tabular}{ccccc}
\hline \multirow{2}{*}{$\boldsymbol{w} / \boldsymbol{c}$} & \multicolumn{2}{c}{ Slump 30-60 $\mathbf{~ m m}$} & \multicolumn{2}{c}{ Slump 60-180 $\mathbf{~ m m}$} \\
\cline { 2 - 5 } & (kondisi SSD) & (kondisi kering udara) & (kondisi SSD) & (kondisi kering udara) \\
\hline 0,40 & 213,33 & 221,44 & 233,33 & 243,40 \\
\hline 0,45 & 213,33 & 221,44 & 233,33 & 243,40 \\
\hline 0,50 & 213,33 & 221,44 & 233,33 & 243,40 \\
\hline 0,55 & 213,33 & 221,44 & 233,33 & 243,40 \\
\hline 0,60 & 213,33 & 221,44 & 233,33 & 243,40 \\
\hline
\end{tabular}


Studi Mengenai Hubungan antara Kelecakan dengan Faktor Air-Semen dan Kadar Air dalam Campuran Beton Cara SNI pada Kondisi Agregat Kering Udara

Tabel 7. Pendekatan Kebutuhan Air [ $\mathrm{kg} / \mathrm{m}^{3}$ ] Cara SNI dalam Campuran Beton untuk Ukuran Maksimum Agregat Kasar 20 mm Kering Udara

\begin{tabular}{ccccc}
\hline \multirow{2}{*}{$\boldsymbol{w} \boldsymbol{c}$} & \multicolumn{2}{c}{ Slump 30-60 $\mathbf{~ m m}$} & \multicolumn{2}{c}{ Slump 60-180 $\mathbf{~ m m}$} \\
\cline { 2 - 5 } & (kondisi SSD) & (kondisi kering udara) & (kondisi SSD) & (kondisi kering udara) \\
\hline 0,40 & 190 & 203,15 & 205 & 223,3 \\
\hline 0,45 & 190 & 203,15 & 205 & 223,3 \\
\hline 0,50 & 190 & 203,15 & 205 & 223,3 \\
\hline 0,55 & 190 & 203,15 & 205 & 223,3 \\
\hline 0,60 & 190 & 203,15 & 205 & 223,3 \\
\hline
\end{tabular}

Tabel 8. Pendekatan Kebutuhan Air $\left[\mathrm{kg} / \mathrm{m}^{3}\right.$ ] Cara SNI dalam Campuran Beton untuk Ukuran Maksimum Agregat Kasar $\mathbf{4 0}$ mm Kering Udara

\begin{tabular}{ccccc}
\hline \multirow{2}{*}{$\boldsymbol{w} \boldsymbol{c}$} & \multicolumn{2}{c}{ Slump 30-60 $\mathbf{~ m m}$} & \multicolumn{2}{c}{ Slump 60-180 $\mathbf{~ m m}$} \\
\cline { 2 - 5 } & (kondisi SSD) & (kondisi kering udara) & (kondisi SSD) & (kondisi kering udara) \\
\hline 0,40 & 170 & 186,90 & 185 & 205,44 \\
\hline 0,45 & 170 & 186,90 & 185 & 205,44 \\
\hline 0,50 & 170 & 186,90 & 185 & 205,44 \\
\hline 0,55 & 170 & 186,90 & 185 & 205,44 \\
\hline 0,60 & 170 & 186,90 & 185 & 205,44 \\
\hline
\end{tabular}

\section{METODE PENELITIAN}

\subsection{Prosedur Penelitian}

Prosedur penelitian yang dilakukan adalah pengkajian literatur, topik penelitian, hubungan antara kelecakan dengan faktor air-semen dan kadar air dalam campuran beton cara SNI pada kondisi agregat kering udara, persiapan alat dan bahan untuk pengujian, merancang komposisi campuran beton menggunakan agregat kering udara dengan faktor air-semen 0,$40 ; 0,45$; 0,50; 0,55; dan 0,60; melakukan uji s/ump, membuat benda uji silinder beton, melakukan perawatan benda uji selama 28 hari, melakukan pengujian kuat tekan beton umur 28 hari, menganalisis data hasil pengujian, dan membuat kesimpulan.

\subsection{Data Penelitian}

Data penelitian yang digunakan yaitu data primer. Data primer yang digunakan adalah data material yang diperoleh berdasarkan hasil pengujian secara fisik yang hasilnya dapat dilihat pada Tabel 9, data komposisi campuran beton menggunakan agregat kering udara berukuran $10 \mathrm{~mm}, 20 \mathrm{~mm}$, dan $40 \mathrm{~mm}$, dengan faktor air-semen 0,40;0,45; 0,50;0,55; dan 0,60 yang hasilnya dapat dilihat pada Tabel 10 sampai dengan Tabel 15, dan data pengujian kuat tekan beton pada umur 28 hari dengan benda uji silinder beton berukuran diameter $10 \mathrm{~cm}$ dengan tinggi $20 \mathrm{~cm}$, dan diameter $15 \mathrm{~cm}$ dengan tinggi $30 \mathrm{~cm}$.

Tabel 9. Hasil Pemeriksaan Sifat Fisik Agregat

\begin{tabular}{llllc}
\hline \multicolumn{1}{c}{ Parameter } & & Semen & $\begin{array}{c}\text { Agregat } \\
\text { Kasar }\end{array}$ & $\begin{array}{c}\text { Agregat } \\
\text { Halus }\end{array}$ \\
\hline Berat jenis kondisi SSD & {$\left[\mathrm{kg} / \mathrm{m}^{3}\right]$} & 3.150 & 2.605 & 2.546 \\
\hline Berat jenis kondisi kering udara & {$\left[\mathrm{kg} / \mathrm{m}^{3}\right]$} & & 2.460 & 2.434 \\
\hline Modulus kehalusan & {$[\mathrm{FM}]$} & & & 2,76 \\
\hline Kadar air kondisi SSD & {$[\%]$} & 6,33 & 5,04 \\
\hline Kadar air kondisi kering udara & {$[\%]$} & 5,44 & 4,38 \\
\hline
\end{tabular}


Tabel 10. Komposisi $1 \mathrm{~m}^{3}$ Campuran Beton Cara SNI dengan Ukuran Maksimum Agregat Kasar 10 mm, dengan Nilai Slump 30 mm - 60 mm

\begin{tabular}{|c|c|c|c|c|c|c|c|}
\hline \multirow[t]{2}{*}{$w / c$} & \multicolumn{2}{|r|}{$\begin{array}{c}\text { Air } \\
{[\mathrm{kg}]}\end{array}$} & \multirow{2}{*}{$\begin{array}{c}\text { Semen } \\
{[\mathrm{kg}]}\end{array}$} & \multicolumn{2}{|r|}{$\begin{array}{l}\text { Pasir } \\
\text { [kg] }\end{array}$} & \multicolumn{2}{|c|}{$\begin{array}{c}\text { Batu Pecah } \\
{[\mathrm{kg}]}\end{array}$} \\
\hline & SSD & Kering udara & & SSD & Kering udara & SSD & Kering udara \\
\hline 0,40 & 213,33 & 221,44 & 533,33 & 693,12 & $687,70+5,41$ (air) & 847,15 & $844,45+2,70$ (air) \\
\hline 0,45 & 213,33 & 221,44 & 474,07 & 730,67 & $725,26+5,41$ (air) & 857,74 & $855,04+2,70$ (air) \\
\hline 0,50 & 213,33 & 221,44 & 426,66 & 764,61 & $759,20+5,41$ (air) & 862,22 & $859,52+2,70$ (air) \\
\hline 0,55 & 213,33 & 221,44 & 387,87 & 795,93 & $790,52+5,41$ (air) & 862,26 & $859,56+2,70$ (air) \\
\hline 0,60 & 213,33 & 221,44 & 355,55 & 825,28 & $819,87+5,41$ (air) & 858,96 & $856,26+2,70$ (air) \\
\hline
\end{tabular}

Tabel 11. Komposisi $1 \mathrm{~m}^{3}$ Campuran Beton Cara SNI dengan Ukuran Maksimum Agregat Kasar 20 mm, dengan Nilai Slump 30 mm - 60 mm

\begin{tabular}{|c|c|c|c|c|c|c|c|}
\hline \multirow[t]{2}{*}{$w / c$} & \multicolumn{2}{|r|}{$\begin{array}{c}\text { Air } \\
{[\mathrm{kg}]}\end{array}$} & \multirow{2}{*}{$\begin{array}{c}\text { Semen } \\
\text { [kg] }\end{array}$} & \multicolumn{2}{|r|}{$\begin{array}{l}\text { Pasir } \\
{[\mathrm{kg}]}\end{array}$} & \multicolumn{2}{|c|}{$\begin{array}{c}\text { Batu Pecah } \\
{[\mathrm{kg}]}\end{array}$} \\
\hline & SSD & Kering udara & & SSD & Kering udara & SSD & Kering udara \\
\hline 0,40 & 190 & 20315 & 475 & 578,18 & $569,41+8,77$ (air & $.073,76$ & $8+4,38$ (air) \\
\hline 0,45 & 190 & 5 & 22 & 14 & $+8,77$ (air) & $1.084,70$ & 8(air) \\
\hline 0,50 & 190 & 203,15 & 380 & 639,76 & $630,99+8,77$ (air) & $1.089,32$ & $1.084,94+4,38$ (air) \\
\hline 0,55 & 190 & 203,15 & 345,45 & 667,66 & $658,89+8,77$ (air) & $1.089,35$ & $1.084,97+4,38$ (air) \\
\hline 0,60 & 190 & 203,15 & 316,67 & 694,28 & $685,51+8,77$ (air) & $1.085,93$ & $1.081,55+4,38$ (air) \\
\hline
\end{tabular}

Tabel 12. Komposisi $1 \mathrm{~m}^{3}$ Campuran Beton Cara SNI dengan Ukuran Maksimum Agregat Kasar 40 mm, dengan Nilai Slump 30 mm - 60 mm

\begin{tabular}{|c|c|c|c|c|c|c|c|}
\hline \multirow[t]{2}{*}{$w / c$} & \multicolumn{2}{|r|}{$\begin{array}{c}\text { Air } \\
{[\mathrm{kg}]}\end{array}$} & \multirow{2}{*}{$\begin{array}{c}\text { Semen } \\
\text { [kg] }\end{array}$} & \multicolumn{2}{|r|}{$\begin{array}{l}\text { Pasir } \\
\text { [kg] }\end{array}$} & \multicolumn{2}{|c|}{$\begin{array}{c}\text { Batu Pecah } \\
{[\mathrm{kg}]}\end{array}$} \\
\hline & SSD & Kering udara & & SSD & Kering udara & SSD & Kering udara \\
\hline 0,40 & 170 & 186,90 & 425 & 523,99 & $512,72+11,27$ (air) & $1.222,64$ & $1.217,01+5,63$ (air) \\
\hline 0,45 & 170 & 186,90 & 377,78 & 553,35 & $542,08+11,27$ (air) & $1.231,66$ & $1.226,03+5,63$ (air) \\
\hline 0,50 & 170 & 186,90 & 340 & 581,00 & $569,73+11,27$ (air) & $1.234,62$ & $1.228,99+5,63$ (air) \\
\hline 0,55 & 170 & 186,90 & 309,09 & 607,39 & $596,12+11,27$ (air) & $1.233,19$ & $1.227,56+5,63$ (air) \\
\hline 0,60 & 170 & 186,90 & 283,33 & 632,84 & $621,57+11,27$ (air) & $1.228,45$ & $1.222,82+5,63$ (air) \\
\hline
\end{tabular}

Tabel 13. Komposisi $1 \mathrm{~m}^{3}$ Campuran Beton Cara SNI dengan Ukuran Maksimum Agregat Kasar 10 mm, dengan Nilai Slump 60 mm - 180 mm

\begin{tabular}{|c|c|c|c|c|c|c|c|}
\hline \multirow{2}{*}{$w / c$} & \multicolumn{2}{|c|}{$\begin{array}{c}\text { Air } \\
{[\mathbf{k g}]}\end{array}$} & \multirow{2}{*}{$\begin{array}{c}\text { Semen } \\
\text { [kg] }\end{array}$} & \multicolumn{2}{|r|}{$\begin{array}{l}\text { Pasir } \\
\text { [kg] }\end{array}$} & \multicolumn{2}{|c|}{$\begin{array}{c}\text { Batu Pecah } \\
{[\mathrm{kg}]}\end{array}$} \\
\hline & SSD & $\begin{array}{l}\text { Kering } \\
\text { udara }\end{array}$ & & SSD & Kering udara & SSD & Kering udara \\
\hline 0,40 & 233,33 & 243,40 & 583,33 & 723,06 & $716,35+6,71$ (air) & 723,06 & $719,70+3,36$ (air) \\
\hline 0,45 & 233,33 & 243,40 & 518,51 & 764,37 & $757,66+6,71$ (air) & 734,39 & $731,03+3,36$ (air) \\
\hline 0,50 & 233,33 & 243,40 & 466,66 & 801,21 & $794,50+6,71$ (air) & 739,58 & $736,22+3,36$ (air) \\
\hline 0,55 & 233,33 & 243,40 & 424,24 & 834,80 & $828,09+6,71$ (air) & 740,30 & $736,94+3,36$ (air) \\
\hline 0,60 & 233,33 & 243,40 & 388,88 & 865,95 & $859,24+6,71$ (air) & 737,66 & $734,30+3,36$ (air) \\
\hline
\end{tabular}


Studi Mengenai Hubungan antara Kelecakan dengan Faktor Air-Semen dan Kadar Air dalam Campuran Beton Cara SNI pada Kondisi Agregat Kering Udara

Tabel 14. Komposisi $1 \mathrm{~m}^{3}$ Campuran Beton Cara SNI dengan Ukuran Maksimum Agregat Kasar 20 mm, dengan Nilai Slump 60 mm - 180 mm

\begin{tabular}{cccccccc}
\hline \multirow{2}{*}{$w / \boldsymbol{c}$} & \multicolumn{3}{c}{$\begin{array}{c}\text { Air } \\
{[\mathbf{k g}]}\end{array}$} & $\begin{array}{c}\text { Semen } \\
{[\mathbf{k g}]}\end{array}$ & & $\begin{array}{c}\text { Pasir } \\
{[\mathbf{k g}]}\end{array}$ & \multicolumn{2}{c}{$\begin{array}{c}\text { Batu Pecah } \\
{[\mathbf{k g}]}\end{array}$} \\
\cline { 2 - 8 } & SSD & Kering udara & & SSD & Kering udara & SSD & Kering udara \\
\hline 0,40 & 205 & 223,3 & 512,50 & 632,24 & $620,04+12,20$ (air) & 948,36 & $942,26+6,10$ (air) \\
\hline 0,45 & 205 & 223,3 & 455,56 & 667,02 & $654,82+12,20$ (air) & 959,86 & $953,76+6,10$ (air) \\
\hline 0,50 & 205 & 223,3 & 410 & 698,81 & $686,61+12,20$ (air) & 965,02 & $958,92+6,10$ (air) \\
\hline 0,55 & 205 & 223,3 & 372,73 & 728,41 & $716,21+12,20$ (air) & 965,57 & $959,47+6,10$ (air) \\
\hline 0,60 & 205 & 223,3 & 341,67 & 756,37 & $744,17+12,20$ (air) & 962,65 & $956,55+6,10$ (air) \\
\hline
\end{tabular}

Tabel 15. Komposisi $1 \mathrm{~m}^{3}$ Campuran Beton Cara SNI dengan Ukuran Maksimum Agregat Kasar 40 mm, dengan Nilai Slump 60 mm - 180 mm

\begin{tabular}{cccccccc}
\hline \multirow{2}{*}{$\boldsymbol{w} / \boldsymbol{c}$} & \multicolumn{3}{c}{$\begin{array}{c}\text { Air } \\
{[\mathbf{k g}]}\end{array}$} & $\begin{array}{c}\text { Semen } \\
{[\mathbf{k g}]}\end{array}$ & & $\begin{array}{l}\text { Pasir } \\
{[\mathbf{k g}]}\end{array}$ & \multicolumn{2}{c}{$\begin{array}{c}\text { Batu Pecah } \\
{[\mathbf{k g}]}\end{array}$} \\
\cline { 2 - 8 } & SSD & Kering udara & & SSD & Kering udara & SSD & Kering udara \\
\hline 0,40 & 185 & 205,44 & 462,50 & 586,29 & $572,66+13,63$ (air) & $1.088,82$ & $1.082,01+6,81$ (air) \\
\hline 0,45 & 185 & 205,44 & 411,11 & 618,08 & $604,45+13,63$ (air) & $1.098,80$ & $1.091,99+6,81$ (air) \\
\hline 0,50 & 185 & 205,44 & 370 & 647,57 & $633,94+13,63$ (air) & $1.102,63$ & $1.095,82+6,81$ (air) \\
\hline 0,55 & 185 & 205,44 & 336,36 & 675,40 & $661,77+13,63$ (air) & $1.101,97$ & $1.095,16+6,81$ (air) \\
\hline 0,60 & 185 & 205,44 & 308,33 & 701,98 & $688,35+13,63$ (air) & $1.097,97$ & $1.091,16+6,81$ (air) \\
\hline
\end{tabular}

\subsection{Variabel Penelitian}

Variabel pada penelitian ini terdiri dari:

(1) nilai slump sebesar $30 \mathrm{~mm}-60 \mathrm{~mm}$, dan $60 \mathrm{~mm}-180 \mathrm{~mm}$;

(2) ukuran maksimum agregat kasar yang digunakan berukuran $10 \mathrm{~mm}, 20 \mathrm{~mm}$, dan 40 $\mathrm{mm}$;

(3) faktor air-semen yang digunakan sebesar 0,40; 0,45; 0,50; 0,55; dan 0,60;

(4) kadar air campuran beton kondisi agregat kering udara.

\subsection{Analisis Data}

Analisis data hasil pengujian dilakukan dengan cara membuat grafik yang menggambarkan hubungan antara nilai s/ump aktual disekitar nilai slump prediksi untuk setiap faktor air-semen yang dirancang.

\section{HASIL PENELITIAN DAN PEMBAHASAN}

\subsection{Hasil Penelitian}

Hasil-hasil penelitian ditunjukkan pada Tabel 16 sampai dengan Tabel 21. 
Tabel 16. Hasil-hasil Pengujian untuk Komposisi $1 \mathrm{~m}^{3}$ Campuran Beton Cara SNI dengan Ukuran Maksimum Agregat Kasar 10 mm, dengan Nilai s/ump 30 mm - 60 mm

\begin{tabular}{|c|c|c|c|c|c|}
\hline$w / c$ & 0,40 & 0,45 & 0,50 & 0,55 & 0,60 \\
\hline SSD & 213,33 & 213,34 & 213,35 & 213,36 & 213,37 \\
\hline Kering Udara & 221,44 & 221,44 & 221,44 & 221,44 & 221,44 \\
\hline Realisasi & 236,76 & 237,24 & 237,63 & 237,94 & 238,20 \\
\hline Semen [kg] & 533,33 & 474,07 & 426,66 & 387,87 & 355,55 \\
\hline Pacir SSD & 693,12 & 730,67 & 764,61 & 795,93 & 825,28 \\
\hline Kering Udara & $\begin{array}{l}687,70+ \\
5,41 \text { (air) }\end{array}$ & $\begin{array}{l}725,26+ \\
5,41 \text { (air) }\end{array}$ & $\begin{array}{l}759,20+ \\
5,41 \text { (air) }\end{array}$ & $\begin{array}{l}790,52+ \\
5,41 \text { (air) }\end{array}$ & $\begin{array}{l}819,87+ \\
5,41 \text { (air) }\end{array}$ \\
\hline Batu & 847,15 & 857,74 & 862,22 & 862,26 & 858,96 \\
\hline Kering Udara & $\begin{array}{l}844,45+ \\
2,70 \text { (air) }\end{array}$ & $\begin{array}{l}855,04+ \\
2,70 \text { (air) }\end{array}$ & $\begin{array}{l}859,52+ \\
2,70 \text { (air) }\end{array}$ & $\begin{array}{l}859,56+ \\
2,70 \text { (air) }\end{array}$ & $\begin{array}{l}856,26+ \\
2,70 \text { (air) }\end{array}$ \\
\hline Umur Pengujian [hari] & 14 & 14 & 14 & 14 & 14 \\
\hline Slump Aktual [mm] & 5 & 10 & 20 & 25 & 30 \\
\hline Kuat Tekan Rata-rata [MPa] & 31,85 & 24,63 & 22,29 & 17,83 & 13,16 \\
\hline $\begin{array}{l}\text { Prediksi Kuat Tekan } 28 \text { Hari } \\
\text { [MPa] }\end{array}$ & 36,19 & 28,00 & 25,33 & 20,27 & 14,96 \\
\hline Kuat Tekan Rencana [MPa] & 48 & 42 & 37 & 31 & 27 \\
\hline
\end{tabular}

Tabel 17. Hasil-hasil Pengujian untuk Komposisi $1 \mathrm{~m}^{3}$ Campuran Beton Cara SNI dengan Ukuran Maksimum Agregat Kasar 20 mm, dengan Nilai S/ump 30 mm - 60 mm

\begin{tabular}{|c|c|c|c|c|c|c|}
\hline & $w / c$ & 0,40 & 0,45 & 0,50 & 0,55 & 0,60 \\
\hline \multirow{3}{*}{ Air [kg] } & SSD & 190 & 190 & 190 & 190 & 190 \\
\hline & Kering Udara & 203,15 & 203,15 & 203,15 & 203,15 & 203,15 \\
\hline & Realisasi & 219,54 & 219,97 & 220,31 & 220,59 & 220,82 \\
\hline \multicolumn{2}{|r|}{ Semen [kg] } & 475 & 422,22 & 380 & 345,45 & 316,67 \\
\hline \multirow{2}{*}{$\begin{array}{l}\text { Pasir } \\
\text { [kg] }\end{array}$} & SSD & 578,18 & 610,14 & 639,76 & 667,66 & 694,28 \\
\hline & Kering Udara & $\begin{array}{l}569,41+ \\
8,77 \text { (air) }\end{array}$ & $\begin{array}{l}601,37+ \\
8,77 \text { (air) }\end{array}$ & $\begin{array}{l}630,99+ \\
8,77 \text { (air) }\end{array}$ & $\begin{array}{l}658,89+ \\
8,77 \text { (air) }\end{array}$ & $\begin{array}{l}685,51+ \\
8,77 \text { (air) }\end{array}$ \\
\hline \multirow{2}{*}{$\begin{array}{c}\text { Batu } \\
\text { Pecah } \\
\text { [kg] }\end{array}$} & SSD & $1.073,76$ & $1.084,70$ & $1.089,32$ & $1.089,35$ & $1.085,93$ \\
\hline & Kering Udara & $\begin{array}{c}1.069,38+ \\
4,38 \text { (air) } \\
\end{array}$ & $\begin{array}{c}1.080,32+ \\
4,38 \text { (air) }\end{array}$ & $\begin{array}{c}1.084,94+ \\
4,38 \text { (air) }\end{array}$ & $\begin{array}{c}1.084,97+ \\
4,38 \text { (air) }\end{array}$ & $\begin{array}{r}1.081,55+ \\
4,38 \text { (air) }\end{array}$ \\
\hline \multicolumn{2}{|c|}{ Umur Pengujian [hari] } & 15 & 14 & 13 & 13 & 12 \\
\hline \multicolumn{2}{|c|}{ Slump Aktual [mm] } & 10 & 20 & 20 & 30 & 30 \\
\hline \multicolumn{2}{|c|}{ Kuat Tekan Rata-rata [MPa] } & 26,54 & 20,81 & 18,26 & 15,29 & 13,38 \\
\hline \multicolumn{2}{|c|}{$\begin{array}{l}\text { Prediksi Kuat Tekan } 28 \text { Hari } \\
\text { [MPa] }\end{array}$} & 30,16 & 23,64 & 21,48 & 17,98 & 16,12 \\
\hline \multicolumn{2}{|c|}{ Kuat Tekan Rencana [MPa] } & 48 & 42 & 37 & 31 & 27 \\
\hline
\end{tabular}


Studi Mengenai Hubungan antara Kelecakan dengan Faktor Air-Semen dan Kadar Air dalam Campuran Beton Cara SNI pada Kondisi Agregat Kering Udara

Tabel 18. Hasil-hasil Pengujian untuk Komposisi $1 \mathbf{~ m}^{3}$ Campuran Beton Cara SNI dengan Ukuran Maksimum Agregat Kasar 40 mm, dengan Nilai Slump 30 mm - 60 mm

\begin{tabular}{|c|c|c|c|c|c|c|}
\hline \multicolumn{2}{|r|}{$w / c$} & \multirow{2}{*}{$\begin{array}{c}0,40 \\
170 \\
\end{array}$} & \multirow{2}{*}{$\begin{array}{c}\mathbf{0 , 4 5} \\
170 \\
\end{array}$} & \multirow{2}{*}{$\begin{array}{c}\mathbf{0 , 5 0} \\
170 \\
\end{array}$} & \multirow{2}{*}{$\begin{array}{c}0,55 \\
170 \\
\end{array}$} & \multirow{2}{*}{$\begin{array}{c}0,60 \\
170 \\
\end{array}$} \\
\hline \multirow{3}{*}{ Air [kg] } & SSD & & & & & \\
\hline & Kering Udara & 186,90 & 186,90 & 186,90 & 186,90 & 186,90 \\
\hline & Realisasi & 204,20 & 204,58 & 204,89 & 205,14 & 205,34 \\
\hline \multicolumn{2}{|c|}{ Semen [kg] } & 425 & 377,78 & 340 & 309,09 & 283,33 \\
\hline \multirow[b]{2}{*}{$\begin{array}{l}\text { Pasir } \\
\text { [kg] }\end{array}$} & SSD & 523,99 & 553,35 & 581,00 & 607,39 & 632,84 \\
\hline & Kering Udara & $\begin{array}{c}512,72+ \\
11,27 \text { (air) }\end{array}$ & $\begin{array}{c}542,08+ \\
11,27 \text { (air) }\end{array}$ & $\begin{array}{c}569,73+ \\
11,27 \text { (air) }\end{array}$ & $\begin{array}{c}596,12+ \\
11,27 \text { (air) }\end{array}$ & $\begin{array}{c}621,57+ \\
11,27 \text { (air) }\end{array}$ \\
\hline \multirow{2}{*}{$\begin{array}{c}\text { Batu } \\
\text { Pecah } \\
\text { [kg] }\end{array}$} & SSD & $1.222,64$ & $1.231,66$ & $1.234,62$ & $1.233,19$ & $1.228,45$ \\
\hline & Kering Udara & $\begin{array}{c}1.217,01+ \\
5,63 \text { (air) }\end{array}$ & $\begin{array}{c}1.226,03+ \\
5,63 \text { (air) }\end{array}$ & $\begin{array}{c}1.228,99+ \\
5,63 \text { (air) }\end{array}$ & $\begin{array}{c}1.227,56+ \\
5,63 \text { (air) }\end{array}$ & $\begin{array}{c}1.222,82+ \\
5,63 \text { (air) }\end{array}$ \\
\hline \multicolumn{2}{|c|}{ Umur Pengujian [hari] } & 9 & 9 & 8 & 8 & 8 \\
\hline \multicolumn{2}{|c|}{ Slump Aktual [mm] } & 55 & 30 & 30 & 50 & 50 \\
\hline \multicolumn{2}{|c|}{ Kuat Tekan Rata-rata [MPa] } & 20,94 & 17,68 & 17,54 & 17,68 & 16,41 \\
\hline \multicolumn{2}{|c|}{$\begin{array}{l}\text { Prediksi Kuat Tekan } 28 \text { Hari } \\
{[\mathrm{MPa}]}\end{array}$} & 28,29 & 25,26 & 25,06 & 23,90 & 23,44 \\
\hline \multicolumn{2}{|c|}{ Kuat Tekan Rencana [MPa] } & 48 & 42 & 37 & 31 & 27 \\
\hline
\end{tabular}

Tabel 19. Hasil-hasil Pengujian untuk Komposisi $1 \mathbf{~ m}^{3}$ Campuran Beton Cara SNI dengan Ukuran Maksimum Agregat Kasar 10 mm, dengan Nilai S/ump 60 mm - 180 mm

\begin{tabular}{|c|c|c|c|c|c|}
\hline$w / c$ & 0,40 & 0,45 & 0,50 & 0,55 & 0,60 \\
\hline SSD & 233,33 & 233,33 & 233,33 & 233,33 & 233,33 \\
\hline Kering Udara & 243,40 & 243,40 & 243,40 & 243,40 & 243,40 \\
\hline Realisasi & 257,76 & 258,29 & 258,71 & 259,05 & 259,34 \\
\hline Semen [kg] & 583,33 & 518,51 & 466,66 & 424,24 & 388,88 \\
\hline SSD & 723,06 & 764,37 & 801,21 & 834,80 & 865,95 \\
\hline Kering Udara & $\begin{array}{l}\text { 716,35+ } \\
6,71 \text { (air) }\end{array}$ & $\begin{array}{l}757,66+ \\
6,71 \text { (air) }\end{array}$ & $\begin{array}{l}\text { 794,50+ } \\
6,71 \text { (air) }\end{array}$ & $\begin{array}{l}828,09+ \\
6,71 \text { (air) }\end{array}$ & $\begin{array}{l}859,24+ \\
6,71 \text { (air) }\end{array}$ \\
\hline Batu & 723,06 & 734,39 & 739,58 & 740,30 & 737,66 \\
\hline Kering Udara & $\begin{array}{l}\text { 719,70+ } \\
3,36 \text { (air) }\end{array}$ & $\begin{array}{l}\text { 731,03+ } \\
3,36 \text { (air) }\end{array}$ & $\begin{array}{l}\text { 736,22+ } \\
3,36 \text { (air) }\end{array}$ & $\begin{array}{l}\text { 736,94+ } \\
3,36 \text { (air) }\end{array}$ & $\begin{array}{l}\text { 734,30+ } \\
\text { 3,36(air) }\end{array}$ \\
\hline Umur Pengujian [hari] & 19 & 19 & 16 & 16 & 16 \\
\hline Slump Aktual [mm] & 45 & 35 & 60 & 50 & 100 \\
\hline Kuat Tekan Rata-rata [MPa] & 31,42 & 27,39 & 22,93 & 19,53 & 13,16 \\
\hline $\begin{array}{c}\text { Prediksi Kuat Tekan } 28 \text { Hari } \\
{[\mathrm{MPa}]}\end{array}$ & 34,53 & 30,10 & 25,76 & 21,95 & 14,79 \\
\hline Kuat Tekan Rencana [MPa] & 48 & 42 & 37 & 31 & 27 \\
\hline
\end{tabular}


Tabel 20. Hasil-hasil Pengujian untuk Komposisi $1 \mathbf{~ m}^{3}$ Campuran Beton Cara SNI dengan Ukuran Maksimum Agregat Kasar 20 mm, dengan Nilai Slump 60 mm - 180 mm

\begin{tabular}{|c|c|c|c|c|c|}
\hline$w / c$ & 0,40 & 0,45 & $\mathbf{0 , 5 0}$ & 0,55 & 0,60 \\
\hline SSD & 205 & 205 & 205 & 205 & 205 \\
\hline Air $[\mathrm{kg}] \quad$ Kering Udara & 223,3 & 223,3 & 223,3 & 223,3 & 223,3 \\
\hline Realisasi & 238,92 & 239,39 & 239,76 & 240,06 & 240,31 \\
\hline Semen $[\mathrm{kg}]$ & 512,50 & 455,56 & 410 & 372,73 & 341,67 \\
\hline SSD & 632,24 & 667,02 & 698,81 & 728,41 & 756,37 \\
\hline Kering Udara & $\begin{array}{c}620,04+ \\
12,20 \text { (air) }\end{array}$ & $\begin{array}{c}654,82+ \\
12,20 \text { (air) }\end{array}$ & $\begin{array}{c}686,61+ \\
12,20 \text { (air) }\end{array}$ & $\begin{array}{c}716,21+ \\
12,20 \text { (air) }\end{array}$ & $\begin{array}{c}744,17+ \\
12,20 \text { (air) }\end{array}$ \\
\hline Batu & 948,36 & 959,86 & 965,02 & 965,57 & 962,65 \\
\hline Kering Udara & $\begin{array}{l}942,26+ \\
6,10 \text { (air) }\end{array}$ & $\begin{array}{l}953,76+ \\
6,10 \text { (air) }\end{array}$ & $\begin{array}{l}958,92+ \\
6,10 \text { (air) }\end{array}$ & $\begin{array}{l}959,47+ \\
6,10 \text { (air) }\end{array}$ & $\begin{array}{l}956,55+ \\
6,10 \text { (air) }\end{array}$ \\
\hline Umur Pengujian [hari] & 12 & 11 & 11 & 11 & 11 \\
\hline Slump Aktual [mm] & 35 & 60 & 70 & 80 & 120 \\
\hline \multirow{2}{*}{$\begin{array}{c}\text { Kuat Tekan Rata-rata [MPa] } \\
\text { Prediksi Kuat Tekan } 28 \text { Hari } \\
\text { [MPa] }\end{array}$} & 26,33 & 22,93 & 18,68 & 15,92 & 12,74 \\
\hline & 31,72 & 28,66 & 23,35 & 19,90 & 15,92 \\
\hline Kuat Tekan Rencana [MPa] & 48 & 42 & 37 & 31 & 27 \\
\hline
\end{tabular}

Tabel 21. Hasil-hasil Pengujian untuk Komposisi $1 \mathrm{~m}^{3}$ Campuran Beton Cara SNI dengan Ukuran Maksimum Agregat Kasar 40 mm, dengan Nilai Slump 60 mm - 180 mm

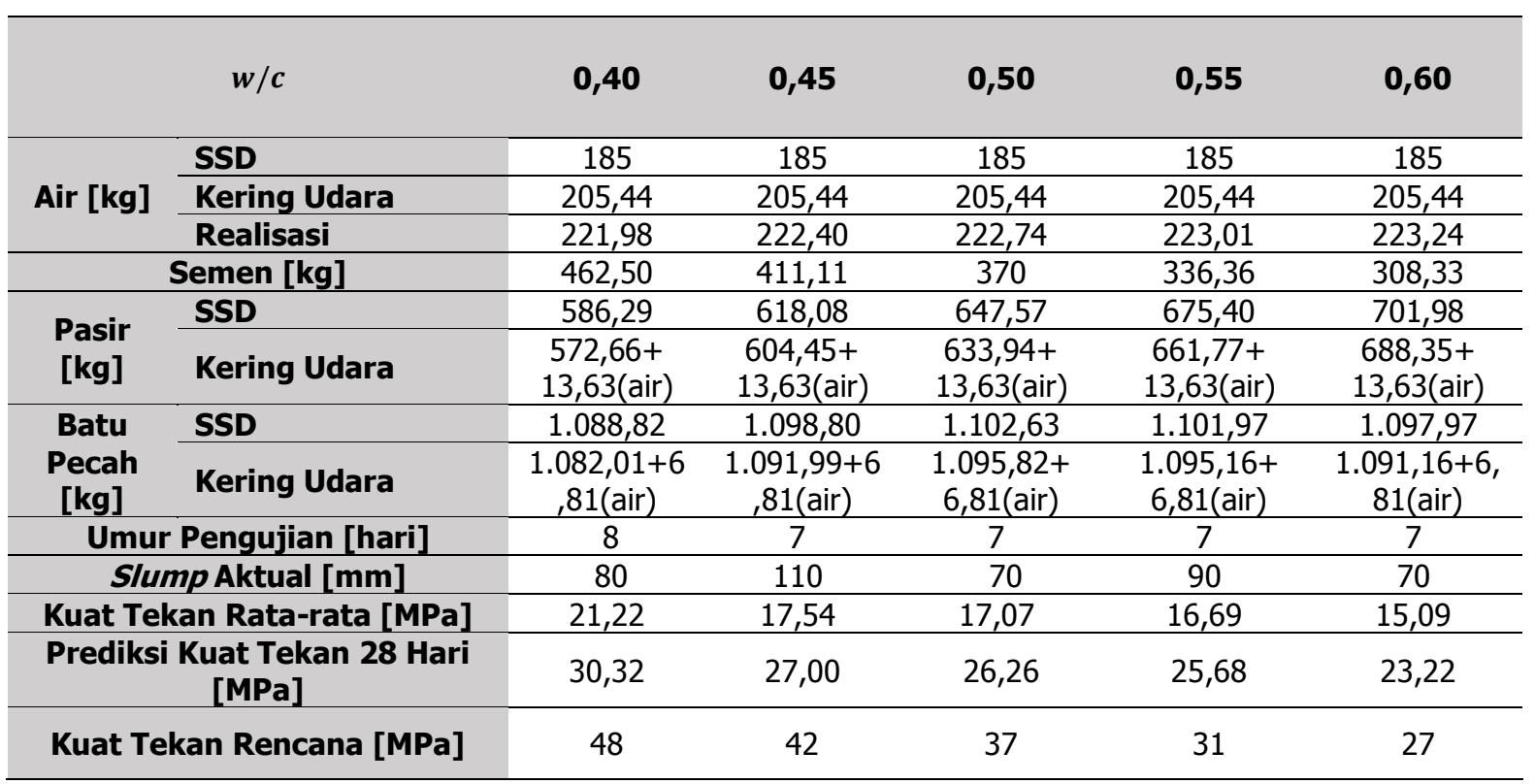

\subsection{Pembahasan Hasil Penelitian}

Jumlah air yang diberikan untuk kondisi kering udara dihitung berdasarkan cara Dreux (Perancis) karena cara ini menggunakan kondisi agregat kering udara. Berdasarkan hasil pengujian maka dapat diungkapkan hal-hal sebagai berikut:

1. Berdasarkan nilai s/ump yang terjadi untuk berbagai faktor air-semen, nilai slump berada pada rentang yang sama untuk jumlah air yang relatif sangat berdekatan. Hal ini mengindikasikan bahwa kelecakan tidak mempunyai hubungan dengan faktor air-semen, tetapi hanya ditentukan oleh kadar air dalam campuran beton, dan ukuran maksimum butiran agregat kasar.

2. Secara umum nilai slump yang terjadi menggunakan jumlah air kering udara cara Dreux jauh lebih rendah daripada nilai s/ump yang direncanakan untuk agregat kondisi kering 
Studi Mengenai Hubungan antara Kelecakan dengan Faktor Air-Semen dan Kadar Air dalam Campuran Beton Cara SNI pada Kondisi Agregat Kering Udara

udara. Hal ini menandakan kondisi kering udara yang digunakan berbeda dengan kondisi kering udara pada metode Dreux yang diterapkan di Perancis. Untuk mencapai nilai slump yang direncanakan maka ditambahkan sejumlah air pada agregat sebelum agregat dicampur dalam adukan beton, dengan asumsi bahwa tambahan air ini akan diserap agregat, sehingga tidak merubah faktor air-semen dan akan mengakibatkan kuat tekan tidak mengalami pengurangan.

3. Berdasarkan nilai s/ump aktual yang seharusnya sama dengan nilai s/ump rencana, maka nilai slump aktual yang lebih rendah dari nilai slump rencana mengindikasikan bahwa kondisi agregat kering udara yang terjadi berbeda dengan kondisi agregat kering udara yang terdapat pada Gambar 1 yang berlaku di wilayah non-tropis. Untuk wilayah tropis, kondisi agregat lebih kering dibandingkan di wilayah non-tropis sehingga untuk mendapatkan kelecakan yang sama memerlukan jumlah air yang lebih besar. Oleh karena itu, jumlah air pada Tabel 6, Tabel 7, dan Tabel 8 dimana kelecakan campuran beton hanya dipengaruhi oleh jumlah air dan ukuran butiran, masih harus dikembangkan lagi untuk kondisi tropis karena jumlah air pada tabel tersebut diturunkan langsung berdasarkan grafik pada Gambar 1.

4. Nilai kuat tekan dengan faktor air-semen yang rendah seharusnya memiliki nilai kuat tekan yang tinggi. Akan tetapi, dari hasil pengujian nilai kuat tekan yang diperoleh tidak mencapai kuat tekan rencana. Hal tersebut diduga bahwa kuat tekan tidak hanya dipengaruhi oleh faktor air-semen, tetapi juga dipengaruhi oleh faktor lain.

\section{KESIMPULAN DAN SARAN}

\subsection{Kesimpulan}

Dari hasil pengujian dan pembahasan yang dilakukan pada penelitian ini maka dapat disimpulkan:

1. Kelecakan tidak dipengaruhi faktor air-semen tetapi hanya dipengaruhi oleh jumlah air dan ukuran butiran agregat.

2. Kebutuhan jumlah air yang diajukan masih harus disesuaikan dengan kondisi di wilayah tropis.

\subsection{Saran}

Perlu dilakukan penelitian lebih lanjut untuk mendapatkan jumlah air untuk mencapai suatu kelecakan pada kondisi wilayah tropis.

\section{DAFTAR RUJUKAN}

Arjanggi, S. D. (2012). Tinjauan Mengenai Relasi antara Kelecakan Beton Segar, Faktor AirSemen, dan Komposisi Bahan dalam Campuran Beton. Tugas Akhir. Bandung: Jurusan Teknik Sipil Institut Teknologi Nasional - Bandung.

Azka, A. (2016). Studi Tentang Faktor Granular Tinggi pada Perancangan Campuran Beton Cara Dreux Gorrise. Tugas Akhir. Bandung: Jurusan Teknik Sipil Institut Teknologi Nasional - Bandung.

Badan Standardisasi Nasional. (2000). SNI 03-2834-2000 Tata Cara Pembuatan Rencana Campuran Beton Normal. Jakarta: Badan Standardisasi Nasional.

Mulyono, T. (2003). Teknologi Beton. Yogyakarta: Penerbit Andi. 